\title{
EXPLORING THE ROLE OF MOTIVATION IN ENHANCING UNIVERSITY STUDENTS' ORAL PERFORMANCE IN EFL CLASSROOMS
}

\author{
${ }^{1}$ Ramadani, F. ${ }^{2}$ Arbain, M. ${ }^{3}$ Novika, H. \\ Islamic University of Kalimantan \\ rookiefitra85@gmail.com
}

\begin{abstract}
This research is intended to find out the factors influencing the university students' motivation in learning English speaking skill, and the efforts carried out to motivate the university students to speak English. The design employed in this research report belongs to descriptive research. The result of research finding concerning with some factors influencing the university students' motivation in learning English speaking skill shows that students' age gender has the highest percentage (97\%), frequency of attendance and degree of students' interest to oral expression (89\%) and Students' gender distribution(81\%), whereas particularly dealing with students' opinions about the most used teaching strategies ('using materials (videos and music)' and 'group/pair work') has the lowest percentage $(21 \%)$. Meanwhile the result of research finding concerning with the strategies carried out to motivate the university students to speak English, degree of teaching strategies' use has the highest percentage (99.9\%).
\end{abstract}

Key words: motivation, speaking, strategies

\section{INTRODUCTION}

It is not easy for students to practice English speaking skill as a second or foreign language fluently. Many obstacles are frequently faced while they are practicing their oral skill. It is commonly believed that one of the most significant reasons of the students' failure is low motivation. They tend to be discouraged during the speaking class, and difficult to perform their speaking skill appropriately. Consequently, they still have difficulties generating and delivering ideas spontaneously. Students feel reluctant to perform English in classroom because they are less motivated to speak. This occurs due to many other reasons, such as, lack of confidence in speaking and the fear of making errors in language 
while speaking. The lack of conversation class also limits their opportunities for learning new things in a classroom. Hue (2010) asserts that lack of motivation gives way to further lack of motivation. This situation requires English lecturers to apply various appropriate methods, approaches, techniques and media in order to encourage students to speak English.

An English lecturer/teacher actually plays crucial role in making the class environment appropriate for speaking and encouraging the students to talk by using different ways. Concerning with this, Madsa (2012) assumes that the good environment gives confidence to EFL students to speak correctly. Thus, lecturers are responsible for creating conducive learning environment, such as reducing their nervousness, fear and anxiety by making it easy for them with, for examples supporting words, organizing the seats of the classroom in a circle or in group with the students facing each other allowing them to speak English sitting in their seats so as to become more relaxed, letting university students majoring English show what they have prepared for a certain topic in advance, and dividing the students into pairs and groups. Apparently, it is important to make a proper atmosphere where the students will not feel shy, so they will volunteer to ask a question, give an answer, and give an opinion. Mahdi (2015) argued that some students get inspired through challenges while other ones require teacher's approval to motivate them. Ellis (1994) as cited by Aggouni (2015, p. 30) clarifies that effective language teachers should be energetic and creative because of the risk of losing motivation easily. Learners are motivated when they have firm belief in their job and career prospects, while the students, who are doubtful about it, are less motivated. It is believed that learner's motivation and their linguistic performance are interrelated each other. One of the principles for attaining mastery in teaching is motivating students especially the ones who are considered reluctant to participate, speak or engage in a classroom (Weimer, 2009).

Gardner and Lambert (1995) as cited in Mehrpour\&Vojdani (2012, p. 44) identify two types of motivation; instrumental and integrative motivation. Instrumental motivation refers to the desire to learn a language because it will 
be useful for certain "instrumental" goals, such as getting a job, passing an examination or reading a foreign newspaper. Meanwhile integrative motivation refers to the desire to learn a language in order to communicate with people of another culture who speak.

The study dealing with motivation had been done in different places such as Hartford \& Ontario (Mehrpour\&Vojdani, 2012, p. 44) that revealed that motivation is a critical factor in students' success, and students with integrative orientation/direction are more successful than those with instrumental motivation. Meanwhile Arbain (2017) in his research for senior high school students found that one of the serious problems encountered by students was low motivation in practicing speaking in front of class.

Based on the background described above, the research is intended to find out the factors influencing the university students' motivation in learning English speaking skill, and the efforts carried out to motivate the university students to speak English

\section{METHODOLOGY}

The design employed in this research report belongs to descriptive research design, which is designed to address the research questions involving (1) the factors influencing the university students' motivation in practicing English speaking skill and (2) efforts carried out to motivate the university students to speak English.

The data are collected from (1) the factors influencing the students' motivation in practicing English speaking skill and (2) the efforts carried out to motivate the students to speak English.

The source of the data is taken from questionnaires. The students are given questionnaires to get the data concerning with (1) the factors influencing the students' motivation in learning English speaking skill and (2) the efforts carried out to motivate the students to speak English. 
100 university students are taken as samples. In addition, there are also three samples for three lecturers who will participate in this investigation.

In this research, questionnaire is used as the technique of collecting the data. Thus, the data instruments used in this research are questionnaires for both university students and English lecturers.

\section{FINDINGS AND DISCUSSION}

The Factors Influencing the University Students' Motivation in Practicing English Speaking Skill.

\begin{tabular}{|c|c|c|}
\hline Options & Answers & $\%$ \\
\hline $19-21$ & 97 & $97 \%$ \\
\hline $22-24$ & 3 & $3 \%$ \\
\hline+25 & 0 & $00 \%$ \\
\hline Total & 100 & $100 \%$ \\
\hline
\end{tabular}

Table 01: Students' Age

The table shows that $97 \%$ of the students are between nineteen (19) to twenty-one (21) years old. $3 \%$ of the students are between twenty-two (22) to twenty-four (24) years old, while $0 \%$ are over twenty-five (25) years old.

\begin{tabular}{|c|c|c|}
\hline Options & Answers & $\%$ \\
\hline Female & 29 & $81 \%$ \\
\hline Male & 07 & $19 \%$ \\
\hline Total & 100 & $100 \%$ \\
\hline
\end{tabular}

Table 02: Students' Gender Distribution

The Table shows that a majority of the participants who have answered this questionnaire are females (29) out of (36).

\begin{tabular}{|l|c|c|}
\hline \multicolumn{1}{|c|}{ Options } & Answers & $\%$ \\
\hline Chosen by you? & 69 & $69 \%$ \\
\hline Recommended by others? & 09 & $9 \%$ \\
\hline Chosen without reason? & 22 & $22 \%$ \\
\hline \multicolumn{1}{|c|}{ Total } & 100 & $100 \%$ \\
\hline
\end{tabular}

Table 03: The Source to Study English 
The graph illustrates that $69 \%$ of the students have chosen to study English; $9 \%$ of them have been recommended by others to study, whereas, $22.9 \%$ from them have no reason to select it as a branch.

\begin{tabular}{|c|c|c|}
\hline Options & Answers & $\%$ \\
\hline Listening & 28 & $28 \%$ \\
\hline Speaking & 39 & $39 \%$ \\
\hline Reading & 03 & $3 \%$ \\
\hline Writing & 30 & $30 \%$ \\
\hline (n) & 100 & $100 \%$ \\
\hline
\end{tabular}

Table 04: Students' Opinions about the Most Difficult Skill

It can be seen from the graph that $39 \%$ from the participants have found speaking the most difficult skill to master. After that, there is writing with $30 \%$ and listening with $28 \%$. Apparently, the less difficult is reading (3\%).

\begin{tabular}{|c|c|c|}
\hline \multicolumn{1}{|c|}{ Options } & Answers & $\%$ \\
\hline Writing & 25 & $25 \%$ \\
\hline Speaking & 75 & $75 \%$ \\
\hline Total & 96 & $100 \%$ \\
\hline
\end{tabular}

Table 05: Students' Opinions about the Most Interesting Skill

The graph reveals that between writing and speaking, a large number of the students (75\%) have found that speaking is the most interesting skill in learning the language. whereas, writing is only $25 \%$.

\begin{tabular}{|c|c|c|}
\hline Options & Answers & $\%$ \\
\hline Easy & 42 & $42 \%$ \\
\hline Difficult & 58 & $58 \%$ \\
\hline Total & 100 & $100 \%$ \\
\hline
\end{tabular}

Table 06: Students' Opinions about Speaking English

From the graph, it is clear that $58 \%$ from the participants have considered speaking English as a difficult task.

\begin{tabular}{|c|c|c|}
\hline Options & Answers & $\%$ \\
\hline Always & 89 & $89 \%$ \\
\hline Sometimes & 06 & $6 \%$ \\
\hline rarely & 05 & $5 \%$ \\
\hline Total & 100 & $100 \%$ \\
\hline
\end{tabular}

Table 07: Frequency of Attendance 
The table represents $89 \%$ from the participants have always attended oral sessions. However, $11 \%$ from them have sometimes attended oral sessions and $5 \%$ from them have rarely been there.

\begin{tabular}{|lc|c|c|}
\hline \multicolumn{1}{|c|}{ Options } & Answers & $\%$ \\
\hline Yes & & 78 & $78 \%$ \\
\hline No & & 22 & $22 \%$ \\
\hline \multicolumn{2}{|c|}{ Total } & 100 & $100 \%$ \\
\hline
\end{tabular}

Table 08: Degree of Students' Participation

As can be seen from the table, $78 \%$ from the students participate during oral classes.

\begin{tabular}{|l|c|c|}
\hline \multicolumn{1}{|c|}{ Options } & Answers & $\%$ \\
\hline Always & 29 & $29 \%$ \\
\hline Sometimes & 39 & $39 \%$ \\
\hline Rarely & 28 & $28 \%$ \\
\hline Never $\quad$ Total & 4 & $4 \%$ \\
\hline \multicolumn{2}{|c|}{100} & $100 \%$ \\
\hline
\end{tabular}

Table 09: Rate of Participation during Oral Classes

As the graph shows, the high rate (39\%) is about the students who sometimes participate during oral classes. After that, $28 \%$ are those who rarely practice their speaking skill and $29 \%$ are the ones who are always involved in oral sessions. Apparently, only 4\% do not participate.

\begin{tabular}{|c|c|c|}
\hline Options & Answers & $\%$ \\
\hline Excited & 38 & $38 \%$ \\
\hline Nervous & 44 & $44 \%$ \\
\hline Bored & 18 & $18 \%$ \\
\hline Total & 100 & $100 \%$ \\
\hline
\end{tabular}

Table 10: Students' Attitudes towards Oral Session

As it is shown by the graph, $38 \%$ from the participants are exited during oral sessions. However, $44 \%$ feel nervous and $18 \%$ feel bored.

\begin{tabular}{|l|c|c|}
\hline \multicolumn{1}{|c|}{ Options } & Answers & $\%$ \\
\hline Teachers & 16 & $16 \%$ \\
\hline Classmates & 22 & $22 \%$ \\
\hline Lack of preparation & 62 & $62 \%$ \\
\hline Total & 100 & $100 \%$ \\
\hline
\end{tabular}

Table 11: Sources of Anxiety in Oral Classes 
It is clear from the graph that $62 \%$ from the students are afraid during oral sessions due to the lack of preparation. $22 \%$ are anxious from their classmates while $16 \%$ are afraid of their teachers.

\begin{tabular}{|l|c|c|}
\hline \multicolumn{1}{|c|}{ Options } & Answers & $\%$ \\
\hline Always & 42 & $42 \%$ \\
\hline Sometimes & 40 & $40 \%$ \\
\hline Rarely & 18 & $18 \%$ \\
\hline Never & 00 & $00 \%$ \\
\hline Total & 100 & $100 \%$ \\
\hline
\end{tabular}

Table 12: Mistakes' Correction during an Oral Performance

It is clear from the table that $42 \%$ from the participants have stated that their teachers have always corrected their mistakes, and another $40 \%$ have argued that they do sometimes. However, $18 \%$ have answered that they do rarely.

\begin{tabular}{|c|c|c|}
\hline Options & Answers & $\%$ \\
\hline Yes & 89 & $89 \%$ \\
\hline No & 11 & $11 \%$ \\
\hline Total & 100 & $100 \%$ \\
\hline
\end{tabular}

Table 13: Degree of Students' Interest to Oral Expression

As can be seen from the table, a significant number of the participants (89\%) have interest in oral expression. Meanwhile, $11 \%$ considered that oral expression is not interesting.

\begin{tabular}{|c|c|c|}
\hline Options & Answers & $\%$ \\
\hline Advanced & 22 & $22 \%$ \\
\hline Average & 61 & $61 \%$ \\
\hline Beginner & 27 & $27 \%$ \\
\hline Total & 100 & $100 \%$ \\
\hline
\end{tabular}

Table 14: Students' Level in Speaking English

As it is illustrated by the graph, 61\% have considered themselves as average in speaking English. However, 27\% are beginners and 22\% are advanced.

\begin{tabular}{|l|c|c|}
\hline \multicolumn{1}{|c|}{ Options } & Answers & $\%$ \\
\hline Encouragement from teachers & 31 & $31 \%$ \\
\hline Competing your classmates & 16 & $16 \%$ \\
\hline Improving your speaking ability & 53 & $53 \%$ \\
\hline \multicolumn{1}{|c|}{ Total } & 100 & $100 \%$ \\
\hline
\end{tabular}

Table 15: Students' Motivating Factor during Oral Classes 
The table represents $53 \%$ of the students are motivated because of their drive to enhance their speaking ability. On the other hand, $31 \%$ are encouraged by their teachers, and $16 \%$ become motivated when they are challenging their classmates.

\begin{tabular}{|l|c|c|}
\hline \multicolumn{1}{|c|}{ Options } & Answers & $\%$ \\
\hline Always & 21 & $21 \%$ \\
\hline Sometimes & 76 & $76 \%$ \\
\hline Never Total & 03 & $03 \%$ \\
\hline \multicolumn{2}{|c|}{ To } & $100 \%$ \\
\hline
\end{tabular}

Table 16: Degree of Students' Interests to their Speaking Topics

From the table, it is clear that a high percentage of the students (76\%) have sometimes found the chosen subjects motivating. However, $21 \%$ are always motivated by the selected subjects, and $3 \%$ have found the subjects unexciting.

\begin{tabular}{|c|c|c|}
\hline Options & Answers & $\%$ \\
\hline Yes & 82 & $82 \%$ \\
\hline No & 18 & $18 \%$ \\
\hline Total & 100 & $100 \%$ \\
\hline
\end{tabular}

Table 17: Degree of Lecturer's Motivation in Classrooms

From the graph, it is clear that $82 \%$ of the participants have agreed that their teachers motivate them in the classrooms. On the other hands, $18 \%$ of the participants do not agree that their teachers motivate them in the classrooms.

\begin{tabular}{|c|c|c|}
\hline Options & Answers & $\%$ \\
\hline De-motivating & 34 & $34 \%$ \\
\hline Helpful & 66 & $66 \%$ \\
\hline Total & 100 & $100 \%$ \\
\hline
\end{tabular}

Table 18: Teacher's Obligation to Participate in Oral Sessions

It can be seen from the graph that a significant number of the students $(66 \%)$ have stated that obliging them to speak in the classroom is helpful. However, $34 \%$ are de-motivated because of the teachers' oblige to participate.

\begin{tabular}{|c|c|c|}
\hline Options & Answers & $\%$ \\
\hline They encourage you & 49 & $49 \%$ \\
\hline They Stress you & 31 & $31 \%$ \\
\hline You are not interested & 20 & $20 \%$ \\
\hline Total & 100 & $100 \%$ \\
\hline
\end{tabular}


Table 19: Effect of Classmates' Fluency in English

The table shows that $49 \%$ of the participants are encouraged by their classmates' fluency while speaking English. On the other hand, 31\% are stressed and $20 \%$ are not interested.

\begin{tabular}{|l|c|c|}
\hline \multicolumn{1}{|c|}{ Options } & Answers & $\%$ \\
\hline Always & 41 & $41 \%$ \\
\hline Sometimes & 59 & $59 \%$ \\
\hline Never Total & 00 & $00 \%$ \\
\hline \multicolumn{2}{|c|}{ Tabl $20 \mathrm{Freque}$} \\
\hline
\end{tabular}

Table 20: Frequency of Concentration in Oral Sessions

The graph indicates that $59 \%$ of the participants can sometimes give the full attention during oral classes; whereas, $41 \%$ are always concentrating.

\begin{tabular}{|c|c|c|}
\hline Options & Answers & $\%$ \\
\hline Yes & 76 & $76 \%$ \\
\hline No & 24 & $24 \%$ \\
\hline Total & 100 & $100 \%$ \\
\hline
\end{tabular}

Table 21: Degree of Required Preparation to Help in Motivating Students

As it is shown by the graph, a large number of the students (76\%) need preparation so they can participate in oral classes. Meanwhile, the rest of the students $(24 \%)$ state that they do not need preparation.

\begin{tabular}{|c|c|c|}
\hline Options & Answers & $\%$ \\
\hline Yes & 62 & $62 \%$ \\
\hline No & 38 & $38 \%$ \\
\hline Total & 96 & $100 \%$ \\
\hline
\end{tabular}

Table 22: Degree of Using Strategies in Learning English

It can be seen from the graph that a high number of the students $(62 \%)$ have used learning strategies. Meanwhile the others (38\%) admitted that they did not use any strategy in their learning.

\begin{tabular}{|c|c|c|}
\hline Options & Answers & $\%$ \\
\hline Practicing & 28 & 28 \\
\hline Watching videos & 22 & 22 \\
\hline Encouraging yourself & 19 & 19 \\
\hline Asking questions & 11 & 11 \\
\hline Cooperating with others & 20 & 20 \\
\hline Total & 100 & $100 \%$ \\
\hline
\end{tabular}


Table 23: Students' Preferred Strategies during Oral Classes

It can be seen from the table that $28 \%$ use 'practicing' as a leaning strategy. $22 \%$ of the participants watch videos to improve their speaking skill while $20 \%$ cooperate with each other in the classrooms. However, $19 \%$ encourage themselves to succeed, and $11 \%$ keep asking questions in the oral classes.

\begin{tabular}{|l|c|c|}
\hline \multicolumn{1}{|c|}{ Options } & Answers & $\%$ \\
\hline Gestures / language body & 10 & 10 \\
\hline Repetition and chances for practicing & 20 & 20 \\
\hline Use of materials (videos and music) & 21 & 21 \\
\hline Using pictures & 09 & 09 \\
\hline Group / pair work & 21 & 21 \\
\hline Role - playing Total & 19 & 19 \\
\hline \multicolumn{2}{|c|}{100} & $100 \%$ \\
\hline
\end{tabular}

Table 24: Students' Opinions about the Most Used Teaching Strategies

From the table, it is clear that the most used strategies by teachers are 'using materials (videos and music)' and 'group/pair work' where the percentage for each strategy is $21 \%$. After that, $20 \%$ agree that teachers use 'repetition and providing chances for practicing'. 19\% consider 'role - playing' as the most used strategy, and then, $10 \%$ state that the strategy, which is often used, is 'language body/ gestures'. At the end, 9\% agree with 'using pictures' as the most used strategy.

\begin{tabular}{|c|c|c|}
\hline Options & Answers & $\%$ \\
\hline Yes & 64 & $66 \%$ \\
\hline No & 36 & $36 \%$ \\
\hline Total & 100 & $100 \%$ \\
\hline
\end{tabular}

Table 25: Degree of Lecturer's Use of Modern and Different Strategies

From the graph, it is clear that $64 \%$ of the participants have agreed that their lecturers have used modern teaching strategies in the classroom. It means the other students (36\%) think that their lecturers didnot use modern teaching strategies in the classroom.

The Efforts Carried Out to Motivate the Students to Speak English.

\begin{tabular}{|c|c|c|}
\hline Options & Answers & $\%$ \\
\hline $25-31$ & 00 & $00.0 \%$ \\
\hline
\end{tabular}




\begin{tabular}{|c|c|c|}
\hline $32-38$ & 01 & $33.3 \%$ \\
\hline $39-45$ & 01 & $33.3 \%$ \\
\hline $46-52$ & 01 & $33.3 \%$ \\
\hline $53+$ & 00 & $00.0 \%$ \\
\hline Total & 03 & $99.9 \%$ \\
\hline
\end{tabular}

Table 26: Lecturers' Age Distribution

The graph shows that $33.3 \%$ of the teachers are between thirty-two (32) to thirty-eight (38) years old, thirty-nine (39) to forty-five (45) and forty-six (46) to fifty-two (52) years old are $33.3 \%$ each.

\begin{tabular}{|c|c|c|}
\hline Options & Answers & $\%$ \\
\hline Female & 02 & $66.6 \%$ \\
\hline Male & 01 & $33.3 \%$ \\
\hline Total & 03 & $99.9 \%$ \\
\hline
\end{tabular}

Table 27: Lecturers' Gender Distribution*

As it is shown by the graph, a high percentage of the lecturers who participate in this questionnaire are females (66.6\%). The other one who participates in this questionnaire is male $(33.3 \%)$

\begin{tabular}{|l|c|c|}
\hline \multicolumn{1}{|c|}{ Options } & Answers & $\%$ \\
\hline Less than 5 years & 01 & $33.3 \%$ \\
\hline 6-10 years & 01 & $33.3 \%$ \\
\hline More than 10 years & 01 & $33.3 \%$ \\
\hline Total & 03 & $99.9 \%$ \\
\hline
\end{tabular}

Table 28: English lecturers' teaching experience*

The lecturers 'years of teaching are dissimilar. They are limited between less than five years to more than 10 years. One of the lecturers has been teaching less than five years $(33.3 \%)$, another one has been teaching almost nine years $(33.3 \%)$ and the other one has been teaching more than ten years (33.3\%).

\begin{tabular}{|c|c|c|}
\hline Options & Answers & $\%$ \\
\hline Speaking & 01 & $33.3 \%$ \\
\hline Listening & 02 & $66.6 \%$ \\
\hline Total & 03 & $99.9 \% *$ \\
\hline
\end{tabular}

Table 29: Teachers' Opinions about the Students' Preferred Skill* 
The table indicates that between speaking and listening, $66.6 \%$ of the lecturers have agreed that listening is the preferred skill in the classrooms. And the other lecturer has agreed that speaking is the preferred skill in the classrooms.

\begin{tabular}{|l|l|l|}
\hline \multicolumn{1}{|c|}{ Options } & \multicolumn{1}{c|}{ Answers } \\
\hline Very good & 00 & $00.0 \%$ \\
\hline Good & 01 & $66.6 \%$ \\
\hline Average & 01 & $33.3 \%$ \\
\hline Bad Total & 01 & $00.0 \%$ \\
\hline \multicolumn{1}{|c|}{ Tol } & $99.9 \% *$ \\
\hline
\end{tabular}

Table 30: The Speaking Level of the Students*

As can be seen from the graph, $33.3 \%$ of the teachers have considered their students' level in speaking English as average. However, 66.6\% have stated that they are good.

\begin{tabular}{|c|c|l|}
\hline Options & Answers & \multicolumn{1}{|c|}{$\%$} \\
\hline Yes & 03 & $99.9 \%$ \\
\hline No & 00 & $00.0 \%$ \\
\hline Total & 03 & $99.9 \% *$ \\
\hline
\end{tabular}

Table 31: Degree of Teaching Strategies' Use*

As it is shown by the graph, a significant number of the lecturers (99.9\%) have used teaching strategies in the classrooms.

\begin{tabular}{|l|c|c|}
\hline \multicolumn{1}{|c|}{ Options } & Answers & $\%$ \\
\hline Very satisfied & 00 & $00.0 \%$ \\
\hline Satisfied & 02 & $66.6 \%$ \\
\hline Almost satisfied & 01 & $33.3 \%$ \\
\hline Not at all Total & 00 & $00.0 \%$ \\
\hline \multicolumn{2}{|c|}{ ar } & $99.9 \%$ \\
\hline
\end{tabular}

Table 32: Teachers' Satisfaction with Their Students' Performances

From the graph, it is clear that $66.6 \%$ of the teachers are satisfied with their students 'performances during sessions. Another 33.3\% are almost satisfied.

\begin{tabular}{|l|c|l|}
\hline \multicolumn{1}{|c|}{ Options } & Answers & \multicolumn{1}{c|}{$\%$} \\
\hline Always & 02 & $66.6 \%$ \\
\hline Sometimes & 01 & $33.3 \%$ \\
\hline Never Total & 00 & $00.0 \%$ \\
\hline \multicolumn{2}{|c|}{ To3 } & $99.9 \%^{*}$ \\
\hline
\end{tabular}


Table 33: Frequency of Lecturers' Correction*

The table represents $66.6 \%$ of the teachers who always correct their students' errors. Whereas, $33.3 \%$ sometimes do the correction.

\begin{tabular}{|c|c|c|}
\hline Options & Answers & $\%$ \\
\hline Speaking is difficult & 00 & $00 \%$ \\
\hline The lack of motivation & 03 & $50 \%$ \\
\hline Both & 03 & $50 \%$ \\
\hline Total & 06 & $100 \%$ \\
\hline
\end{tabular}

Table 34: Reasons behind Students' Failure in Speaking English

It is clear from the graph that $100 \%$ of the lecturers have considered both the difficulty of speaking and the lack of motivation as factors that hinder the success to speak English.

\section{CONCLUSION}

The investigation deals with the effect that motivation has a role in stimulating learners to have self-confidence in order to speak in front of their lecturers and classmates. In addition, the study have concentrated on the influence of using different teaching strategies on learners' desire to learn English, and how to help students to overpass their difficulties in speaking so they would be more stimulated to practice their speaking skill.

The analyzed results of lecturers and students' questionnaires showed the strong and positive influence of motivation in encouraging students to acquire the language in the classrooms. Therefore, both lecturers and students should take motivation into consideration during their teaching/learning process.

First year University students' answers supported the hypotheses of this research. Motivation was what had derived most of the participants to improve their speaking ability during classes. In addition, oral expression lecturers mentioned how motivation could lead students' learning to success. They thought that the lack of motivation could be a reason why many students cannot speak the language. Thus, the lecturers had tried to stimulate students to practice their speaking performance through choosing appropriate activities to create 


\section{INTENSIVE JOURNAL \\ http://ojs.uniska-bjm.ac.id/index.php/EJB \\ E-ISSN 2620-4746 \\ April 2020, Vol 3 No.1}

comfortable atmosphere in their classrooms where students worked together and shared their thoughts with each other.

Consequently, the practical part showed the importance of motivation in supporting learners to speak English during oral classrooms.

\section{REFERENCES}

Aziza, Aggouni. (2015). The Role of Motivation in Enhancing Learners' Speaking Performance in English Classrooms - Case study of Third Year LMD Students of English at Biskra University. Algeria: Biskra University (Electronic Thesis).

Arbain, M. (2017). The Students' Problems, Efforts and Expectations in the Speaking Class at MTs Al-InayatutTholibin Banjarmasin. Research Report Funded by APBU. Banjarmasin: UNISKA Banjarmasin. Unpublished Research Report.

Ellis, G, \& Sinclair, B. (1989). Learning to Learn English: A Course in Learning Training. Cambridge: Cambridge University Press.

Hue, N. M. (2010). Encouraging reluctant ESL/EFL learners to speak in the classroom. The Internet TESL Journal, XVI, 3, available at http://iteslj.org/Techniques/Hue-ReluctantSpeakers.html, accessed on 25/05/2017.

Madsa, T. (2012). Motivating Students' Speaking Skill Through Simulation in English for Specific Purposes. 1st Mae FahLuang University International Conference, Thailand, 3-6.

Mahdi, S. D. (2015). Investigating the factors that affect Yemeni students' oral productive performance (Linguistic and NonLinguistic Factors). Unpublished M. A. Thesis. Hodeidah University. Yemen.

Mehrpour, S., \&Vojdani, M. (2012). Globalization and EFL Learning Motivation: A New Perspective on Integrative vs. Instrumental Motivation among Iranian Learners of English. 